\title{
Family Socio-Economic Status and Maternal Health Care Seeking Behaviour in Rural Bangladesh
}

\author{
Delwar Hossain ${ }^{1}$, Muhammad Ilias ${ }^{2}$ \\ ${ }^{I}$ Assistant Professor, Department of Women and Gender Studies, Begum Rokeya University, Rangpur, \\ Bangladesh \\ ${ }^{2}$ Lecturer, Department of Sociology, Begum Rokeya University, Rangpur, Bangladesh
}

\begin{abstract}
This study mainly aims to explore and examine the relationship between family socio-economic status and maternal health care seeking behaviour in rural Bangladesh. This is a total of 200 eligible couples were selected from 3 villages namely Rathni, Beurjari and Udaipur of Baliadangi Upazila through simple random sampling. The selected couples were interviewed by questionnaire method. Frequency distribution, cross-tabulation and partial correlation tests were used to analysis and examine the collected data. These tests suggest that there were significance relationship between family socio-economic status and maternal health care seeking behaviour in rural Bangladesh.
\end{abstract}

Keywords- Bangladesh, Family, Maternal Health, Socio-Economic Status.

\section{INTRODUCTION}

Maternal health care seeking behaviour is one of the most burning issues across the world especially in developing and third world countries. It is an integral part of women's life and indicates the status of women in her family and community. Maternal health care seeking behaviour refers the behavioural patterns of seeking/receiving health care services of women during pregnancy, childbirth and postpartum period. It is the composite result of her personal needs, social forces, the availability, the accessibility, qualification of the care providers, and the place of the services [1-3]. Actually, women have right to receive proper health care services during pregnancy period and after delivery. Pregnancy and the arrival of a new baby is an exciting and life changing time for the parents and their families in any society around the world. But relevant research studies suggest that situation of women in Bangladesh is worse when it comes to their health care seeking behaviours and the services they receive during pregnancy and childbirth and postpartum period [2, 4-5].

In order to ensure proper maternal health care services the government of Bangladesh since her independence has taken many initiatives to promote maternal health care facilities and awareness programs. Some recent studies reveal that many activities and programs that effectively reduce maternal mortality ratio and improve maternal health services in Bangladesh [6-7, 2]. But this scenario is not prevailing equally in both rural and urban areas of the country. Some relevant studies indicate that health care services and care seeking behavior of rural is comparatively low or unofficial channel than urban area of Bangladesh due to distance of health service, cost of service, technical qualifications of health practitioners, women's autonomy of household decision making, people attitude and belief system of rural people, religious and cultural barriers and socioeconomic status of rural people [4-5, 8-11, 2]. Haque indicates that socio-economic status (education, occupation and income) is the most important indicator for utilization of antenatal care, choice of place of delivery, and types of assistance at delivery [12]. Research question on the problem situation: Are there significance relationship between family socio-economic status and maternal health care seeking behaviour in rural Bangladesh? Reviewing empirical studies related to this field in Bangladesh this study found some limitations of the previous studies: 1) there is no specific study on relationship between family socio-economic status attainment and health care seeking behaviour of women in rural Bangladesh; 2) there are substantial knowledge-gap on the relationship between family socio-economic status and maternal health care seeking behaviour in rural Bangladesh. Therefore, the main aim of this study was to explore and examine the relationship between family socio-economic status and maternal health care seeking behaviour in rural Bangladesh. Based on socio-cultural approach these findings of the study may contribute to improve the quality of maternal health care seeking behaviour in relation to their family socio-economic status attainment. 


\section{CONCEPTUAL FRAMEWORK}

Difference of maternal health care seeking behavior in association with couple's socio-economic status is not a new phenomenon in human life. Over the past several decades sociologists and health researchers in respective fields have developed theoretical frameworks or models and its methodology to study, understand and explain variation in maternal health care seeking behavior in relation with couple's socio-economic status across the individual, groups or in a particular society [13].

Regarding this, culture care theory by Leininger; capacity theory by Sen; health seeking behavioural theory by Tipping and Segall; health belief model by Sheeram and Abraham; and behavioural model by Andersen are very popular to explain the problem situation [14-18]. The theoretical frameworks reviewed suggest that healthcare utilization model is more appropriate to study and explain health care seeking behavior of rural women in Bangladesh. This model is used in this study with some modifications.

\begin{tabular}{l}
\hline Family Socio-Economic Status \\
Educational status of both husband \& \\
wife \\
Occupational status of both husband \& \\
wife \\
Family income
\end{tabular}

\section{Health Care Seeking Behaviour}

Medical check-up during pregnancy

Place of childbirth

Birth attendant and

Total number of childbirths

Figure 1: Conceptual framework of family socio-economic status and maternal health care seeking behaviour

\section{BACKGROUND AND METHODOLOGY}

\section{a. Background}

Purpose of the study was to explore and examine relationships between family socio-economic status and maternal health care seeking behaviour in rural Bangladesh. In so doing this study was conducted at Baliadangi Upazila in Thakurgaon District, Bangladesh. In order to conduct this research 3 villages namely Rathni, Beurjhari and Udaipur of the Baliadangi Upazila were purposefully selected. Baliadangi Upazila is a remote Upazila of Thakurgaon District. It is $22 \mathrm{Km}$ west from Thakurgaon. It has 8 Unions with 38932 households and the population is 199660 . The proportions of population of the Baliadangi were almost the same: 51.32 percent for male and 48.68 percent for female [19]. Agriculture and its related work is the main occupation of the people of this area. The Upazila has one health complex where people come to take health care services. The socio-economic status and health care seeking behaviour of boarder based Baliadangi people is quite low than other villages of Bangladesh.

\subsection{Sample}

In order to explore and examine relationship between family socio-economic status and maternal health seeking behaviour a total of 200 couples were selected from 3 villages (Rathni, Beurjari and Udaipur) of Baliadangi Upazila through simple random sampling. First of all we in the study villages of Baliadangi Upazila identified about 1200 eligible couples who have had a previous childbirth and lactating women. This sampling procedure was more eligible, un-biased and scientific to select the samples studied.

\subsection{Variable and Measure}

Socio-Economic Status Characteristics

The main comparison areas of this study were to explore and examine maternal health care seeking behaviours in association with their socio-economic status in rural Bangladesh context. In so doing family socio-economic status used as an independent variable was categorized into education, occupation and annual family income that were converted into ordinal and interval levels. First of all Age of respondent was counted numerically in year. However, selected family socio-economic status characteristics were measured and coded in the following ways:

Education status was numerically measured in years.

Occupation status was nominally measured. For example, Mother's occupation (1= Housewife only, $2=$ Day labouring, $3=$ Small business, and $4=$ Others. Father's occupation ( $1=$ Agricultural work, $2=$ Service, $3=$ Day labouring, $4=$ Small business, $5=$ van puller and $6=$ Others. exchange).

Yearly total income was numerically measured in Taka (1 US\$ $=78$ Bangladesh Taka in currency

Maternal Health Care Seeking Behaviour Characteristics 
This study used maternal health care seeking behaviour as a dependent variable. Health care seeking behaviour of women is not an isolated event; rather, it is an integral part of a woman's status in her family and society. A woman's health care seeking behaviour depend on her personal needs, socio-cultural factors, socioeconomic status, availability and qualifications of the care providers, location of the services and many others factors. In studying women's health care seeking behaviour researchers have used several concepts and its related variables. For example, time between marriage and conception of first child, medical check-up during pregnancy, sexual intercourse during pregnancy, physical work during pregnancy, place of childbirth, birth attendant in first child delivery, total number of childbirths, mother's knowledge about maternal mortality, morbidity and safe motherhood, etc. of women are widely conceptualized. Among these variables this study used key factors of women's health care seeking behaviours, such as medical check-up during pregnancy, place of childbirth, birth attendant in first child delivery, and total number of childbirths. These variables of women's health care seeking behaviour were measured and coded in the following way:

Times of medical check-up was measured in ordinal level $0=$ one time, $1=$ two times, $2=$ four times, $3=$ five times, $4=$ six times, $5=$ seven and more times.

Place of child birth was measured in ordinal level $0=$ govt. hospital, $1=$ private clinic, $2=$ at home, $3=$ others.

Total number of childbirths was numerically measured.

Birth attendant in first child delivery was measured in ordinal level $0=$ trained, $1=$ untrained

\section{INSTRUMENT AND PROCEDURE}

This study used survey design aimed to find out relationship between family socio-economic status and maternal health care seeking behaviour measured above. In so doing we used both qualitative and quantitative variables. Based on the measurement of the independent and dependent variables semi-structural questionnaire with open-ended and close-ended questions was designed.

\section{DATA ANALYSIS}

Based on the main research objective, the analysis of collected data was carried out by SPSS. Frequency distribution, cross-tabulation and partial correlation techniques were applied for more clarity of findings. The findings of the analysis with frequency distribution and test scores were presented in the tabular form.

\section{RESULT}

\subsection{Frequency Distribution of Family Socio-Economic Status and Maternal Health Care Seeking Behaviour:}

The table 1 indicates that socio-economic status (e.g. education, occupation and income) of Baliadangi couples was not satisfactory. Educational level of husbands was $44.0 \%$ in primary, $26.0 \%$ in secondary and no education $22.5 \%$ and their wife's education was $30.0 \%, 51.5 \%$, and $15.0 \%$ respectively. Like educational status, both occupation and income status of Baliadangi couples were not satisfactory. Most of the husband's occupation was agricultural work (49.5\%) and day labouring (40.0\%) and most of the wives were housewives $(89.5 \%)$. The average proportion of yearly income level of both husbands and wives was 10000-19000 Tk. $(48.0 \%)$ and the proportion of $>29000 \mathrm{Tk}$. was only $10.0 \%$. The table 1 also indicates the pattern of health care seeking behaviour of Baliadangi women (e.g. medical check-up during pregnancy period, place of child birth, birth attendant and total number of child birth). Most of the women (50.4\%) of Baliadangi Upazila were out of medical check-up during their pregnancy period and 70.2\% women's place of child birth was at home. Due to place of child birth their birth attendants were untrained $(68.9 \%)$ and most of the women's total numbers of child were 2 which were $45.6 \%$.

Table 1: Frequency Distribution of Family Socio-Economic Status and Maternal Health Care Seeking Behaviour in Baliadangi Upazila, Thakurgaon, Bangladesh 2015

\begin{tabular}{lllc}
\hline $\begin{array}{l}\text { Socio-Economic Status } \\
\text { Characteristics }\end{array}$ & Percent & $\begin{array}{l}\text { Health Care Seeking Behaviour } \\
\text { Characteristics }\end{array}$ & Percent \\
\hline $\begin{array}{l}\text { Education of Husbands } \\
\text { No Education }\end{array}$ & 22.5 & Medical Check-up During Pregnancy \\
Primary & 44.0 & No & 50.4 \\
Secondary & 26.0 & $1-2$ & 36.7 \\
Higher Secondary & 5.0 & $3-4$ & 9.1 \\
Higher Education & 2.5 & $5+$ & 3.2 \\
Education of Wives & & &
\end{tabular}




\begin{tabular}{|c|c|c|c|}
\hline No Education & 15.0 & Place of Child Birth & \\
\hline Primary & 30.0 & Govt. Hospital & 11.7 \\
\hline Secondary & 51.5 & Private Clinic & 18.1 \\
\hline Higher Secondary & 3.5 & Home & 70.2 \\
\hline \multicolumn{4}{|l|}{ Occupation of Husbands } \\
\hline Service (Govt. or Private) & 3.5 & & \\
\hline Agricultural Work & 49.5 & Birth Attendant & \\
\hline Small Business & 2.5 & & \\
\hline Day labouring & 40.0 & Trained & 31.1 \\
\hline Others & 4.5 & Untrained & 68.9 \\
\hline \multicolumn{4}{|l|}{ Occupation of Wives } \\
\hline Housewife & 89.5 & & \\
\hline Day labouring & 8.5 & & \\
\hline Others & 2.0 & Total Number of Child Birth & \\
\hline \multicolumn{4}{|l|}{ Family Income (TK. Yearly) } \\
\hline$<10,000$ & 12.0 & 1 & 41.9 \\
\hline $10,000-19,000$ & 48.0 & 2 & 45.6 \\
\hline $20,000-29,000$ & 30.0 & 3 & 12.5 \\
\hline$>29,000$ & 10.0 & & \\
\hline
\end{tabular}

Source: Fieldwork, 2015

\subsection{Cross-tabulation Result of Family Socio-Economic Status and Maternal Health Care Seeking Behaviour}

Cross-tabulation results on maternal health care seeking behaviours ( e.g. medical check-up during pregnancy period, place of child birth, birth attendant and total number of child birth) varies in association with family socio-economic status (e.g. education, occupation and income) at Baliadangi Upazila of Thakurgaon District, Bangladesh presented in table 2. The table indicates that no education $(22.5 \%$ for husbands, $15 \%$ for wives) and primary education (44.0\% for husbands, $30 \%$ for wives), agricultural work (49.5\%), day labouring $(40.0 \%)$ for husband, housewife $(89.5 \%)$ for wives, and proportion of family income level <10,000, 1000019000, and 20000-29000 Tk. (12.0\% 48.0\% and 30.0\%) were highly associated with no check-up during pregnancy, child birth at home, untrained birth attendant, and two or more child birth. The data tend also indicates that secondary, H. secondary and higher education $(26.0 \%, 5.0 \%, 2.5 \%)$ for husband and secondary, H. secondary education $(51.5 \%, 3.5 \%)$ for wives, service $(3.5 \%)$, and the proportion of yearly family income $>29000$ Tk. were associated with child birth at govt. hospital or clinic, up to 5 times medical check-up during pregnancy, trained birth attendant, and one or two child birth.

Table 2: Cross-tabulation of Family Socio-Economic Status and Maternal Health Care Seeking Behaviour in Baliadangi Upazila, Thakurgaon, Bangladesh 2015

\begin{tabular}{|c|c|c|c|c|c|c|c|c|c|c|c|c|}
\hline $\mathrm{N}=200$ & & & & Wom & 's Hea & th Care $S$ & eeking $t$ & ehavio & & & & \\
\hline SES Status & & edical & heck- & & Plac & of Child & Birth & $\begin{array}{r}\text { B } \\
\text { Atte }\end{array}$ & $\begin{array}{l}\text { rth } \\
\text { idant }\end{array}$ & & $\begin{array}{l}\text { Tumbe } \\
\text { hild B }\end{array}$ & \\
\hline $\begin{array}{l}\text { Education of } \\
\text { Husbands }\end{array}$ & No & $1-2$ & $3-4$ & $5+$ & $\begin{array}{l}\text { Govt } \\
\text { Hos. }\end{array}$ & $\begin{array}{c}\text { Private } \\
\text { Clin. }\end{array}$ & Home & $\begin{array}{l}\text { Trai } \\
\text { ned }\end{array}$ & $\begin{array}{c}\text { Un } \\
\text { Trai. }\end{array}$ & 1 & 2 & 3 \\
\hline No Education & 14.0 & 6.0 & 2.5 & - & - & 2.5 & 20.0 & 2.5 & 20.0 & 4.5 & 15.0 & 3.0 \\
\hline Primary & 27.0 & 12.5 & 4.5 & - & 6.5 & 4.0 & 33.5 & 10.5 & 33.5 & 22.5 & 15.0 & 6.5 \\
\hline Secondary & 8.5 & 12.5 & 5.0 & - & 2.5 & 7.5 & 16.0 & 10.0 & 16.0 & 10.0 & 13.5 & 2.5 \\
\hline $\begin{array}{l}\text { Higher } \\
\text { Secondary }\end{array}$ & - & 1.0 & 3.0 & 1.0 & 1.5 & 2.5 & 1.0 & 5.0 & - & 2.5 & 2.5 & \\
\hline $\begin{array}{l}\text { Higher } \\
\text { Education } \\
\text { Education of } \\
\text { Wives }\end{array}$ & - & - & 2.5 & - & 0.5 & 2.0 & - & 2.5 & - & 0.5 & 2.0 & \\
\hline No Education & 11.0 & 4.0 & - & - & - & 2.5 & 12.5 & 2.5 & 12.5 & 5.0 & 7.5 & 2.5 \\
\hline Primary & 15.0 & 8.0 & 7.0 & - & 5.0 & 5.0 & 20.0 & 10.0 & 20.0 & 16.5 & 10.0 & 3.5 \\
\hline Secondary & 22.5 & 26.0 & 3.0 & - & 6.5 & 10.5 & 34.5 & 17.0 & 34.5 & 17.5 & 25.5 & 8.5 \\
\hline $\begin{array}{l}\text { Higher } \\
\text { Secondary }\end{array}$ & - & 2.5 & 0.5 & 0.5 & 1.0 & 2.5 & - & 3.5 & - & 2.5 & 1.0 & - \\
\hline
\end{tabular}




\begin{tabular}{|c|c|c|c|c|c|c|c|c|c|c|c|c|}
\hline $\begin{array}{l}\text { Occupation } \\
\text { of Husbands }\end{array}$ & & & & & & & & & & & & \\
\hline Service & - & 1.5 & - & 2.0 & 2.5 & 1.0 & - & 3.5 & - & 2.5 & 0.5 & 0.5 \\
\hline $\begin{array}{l}\text { Agricultural } \\
\text { Work }\end{array}$ & 26.0 & 18.0 & 3.5 & 2.0 & 6.0 & 11.0 & 32.5 & 17.0 & 32.5 & 15.0 & 28.0 & 6.5 \\
\hline $\begin{array}{l}\text { Small } \\
\text { Business }\end{array}$ & 0.5 & 2.0 & - & - & - & 1.0 & 1.5 & 1.0 & 1.5 & - & 2.0 & 0.5 \\
\hline $\begin{array}{l}\text { Day } \\
\text { labouring }\end{array}$ & 22.0 & 8.5 & 6.5 & 3.0 & 4.5 & 6.0 & 29.5 & 10.5 & 29.5 & 15.0 & 12.5 & $\begin{array}{l}12 . \\
5\end{array}$ \\
\hline $\begin{array}{l}\text { Others } \\
\text { Occupation } \\
\text { of Wives }\end{array}$ & 1.5 & 3.0 & - & - & 2.0 & - & 2.5 & 2.0 & 2.5 & 3.5 & 1.0 & - \\
\hline Housewife & 51.0 & 35.0 & 3.5 & - & 7.5 & 15.0 & 67.0 & 27.5 & 62.0 & 40.0 & 43.5 & 6.0 \\
\hline $\begin{array}{l}\text { Day } \\
\text { labouring }\end{array}$ & 4.0 & 4.5 & - & - & - & 3.0 & 5.5 & 2.5 & 6.0 & 5.5 & 1.0 & 2.0 \\
\hline $\begin{array}{l}\text { Others } \\
\text { Family } \\
\text { Income (TK. } \\
\text { Yearly) }\end{array}$ & - & 2.0 & - & - & - & 0.5 & 1.5 & 0.5 & 1.5 & 2.0 & - & - \\
\hline$<10,000$ & 8.0 & 4.0 & - & - & 2.5 & - & 9.5 & 2.5 & 9.5 & 10.0 & 2.0 & - \\
\hline $\begin{array}{l}10,000- \\
19,000\end{array}$ & 26.5 & 17.5 & - & 4.0 & 2.0 & 3.0 & 43.0 & 5.0 & 43.0 & 12.5 & 30.0 & 5.5 \\
\hline $\begin{array}{l}20,000- \\
29,000\end{array}$ & 11.0 & 12.5 & 3.0 & 3.5 & 4.5 & 8.0 & 17.5 & 12.5 & 17.5 & 17.0 & 13.0 & - \\
\hline$>29,000$ & 3.5 & 2.5 & 4.0 & - & 3.5 & 3.0 & 3.5 & 7.5 & 2.5 & 5.0 & 2.5 & 2.5 \\
\hline
\end{tabular}

Source: Fieldwork, 2015

\subsection{Relationships between Family SES and Maternal Health Care Seeking Behaviour}

The central objective of this research was to find out relationship between family socio-economic status and maternal health care seeking behaviour in rural Bangladesh. In so doing, we applied partial correlation test. Controlling intervening variable such as knowledge about maternal mortality, overall results of the analysis presented in table 3 reveal that family socio-economic status and maternal health care seeking behaviour were inter-related in study setting at both $\mathrm{P}<0.01, \mathrm{p}<.0 .05$ (in two tailed test) levels. The table indicates that family socio-economic status, especially couple's education, occupation and yearly family income were positively related to times of medical check-up during pregnancy $\left(r^{2}=.306, p=.041 ; r^{2}=.496, p=.003 ;\right.$ and $\left.r^{2}=.584, p=.002\right)$, total number of child birth $\left(r^{2}=.407, p=.010 ; r^{2}=.489, p=.040\right)$, and birth attendant in first child delivery $\left(r^{2}=.497\right.$, $\left.\mathrm{p}=.036 ; \mathrm{r}^{2}=.464, \mathrm{p}=.047\right)$ but negatively related to place of child birth $\left(\mathrm{r}^{2}=-.344, \mathrm{p}=.050\right)$.

Table 3: Results of Partial Correlation Coefficients for the Relationships between Family Socio-Economic Status and Maternal Health Care Seeking Behaviour in Baliadangi Upazila, Thakurgaon, Bangladesh 2015

\begin{tabular}{|c|c|c|c|c|c|c|c|c|}
\hline Variable & 1 & 2 & 3 & 4 & 5 & 6 & 7 & 8 \\
\hline \multicolumn{9}{|l|}{ 1.Husband's Education } \\
\hline 2.Wife's Education & $\begin{array}{l}.464 * * \\
(.003)\end{array}$ & & & & & & & \\
\hline 3.Husband's Occupation & $\begin{array}{l}.072 \\
(.664)\end{array}$ & $\begin{array}{l}-.236 \\
(.148)\end{array}$ & & & & & & \\
\hline 4.Wives' Occupation & $\begin{array}{l}-.205 \\
(.210)\end{array}$ & $\begin{array}{l}-.293 \\
(.070)\end{array}$ & $\begin{array}{l}.207 \\
(.206)\end{array}$ & & & & & \\
\hline 5.Family Income & $\begin{array}{l}.277 \\
(.088)\end{array}$ & $\begin{array}{l}.443^{* *} * \\
(.005)\end{array}$ & $\begin{array}{l}-.450 * * \\
(.004)\end{array}$ & $\begin{array}{l}-.345^{*} \\
(.032)\end{array}$ & & & & \\
\hline 6. Medical Check-up & $\begin{array}{l}.306^{*} \\
(.041)\end{array}$ & $\begin{array}{l}.496^{* *} \\
(.003)\end{array}$ & $\begin{array}{l}.030 \\
(.855)\end{array}$ & $\begin{array}{l}-.141 \\
(.392)\end{array}$ & $\begin{array}{l}.584 * * \\
(.002)\end{array}$ & & & \\
\hline 7.Place of Child Birth & $\begin{array}{l}-.081 \\
(.625)\end{array}$ & $\begin{array}{l}-.344^{*} \\
(.050)\end{array}$ & $\begin{array}{l}-.030 \\
(.858)\end{array}$ & $\begin{array}{l}.094 \\
(.568)\end{array}$ & $\begin{array}{l}-.047 \\
(.778)\end{array}$ & $\begin{array}{l}.268 \\
(.099)\end{array}$ & & \\
\hline 8. Number of Child Birth & $\begin{array}{l}.193 \\
(.399)\end{array}$ & $\begin{array}{l}.070 \\
(.673)\end{array}$ & $\begin{array}{l}.407 * * \\
(.010)\end{array}$ & $\begin{array}{l}-.268 \\
(.099)\end{array}$ & $\begin{array}{l}.489^{*} \\
(.040)\end{array}$ & $\begin{array}{l}-.100 \\
(.544)\end{array}$ & $\begin{array}{l}.028 \\
(.866)\end{array}$ & . \\
\hline
\end{tabular}


Family Socio-Economic Status and Maternal Health Care Seeking Behaviour in Rural Bangladesh

\begin{tabular}{lllllllll}
\hline 9. Birth Attendant & $.497 *$ & .331 & .118 & -.085 & $.464 *$ & -.220 & $.315^{*}$ & $-.682 * *$ \\
& $(.036)$ & $(.427)$ & .475 & $(.607)$ & $(.047)$ & $(.179)$ & $(.051)$ & $(.000)$ \\
\hline$* \mathrm{P}<0.05, * * \mathrm{p}<0.01$ & & &
\end{tabular}

$* \mathrm{P}<0.05, * * \mathrm{p}<.0 .01$

\section{DISCUSSION}

Purpose of the study was to explore and examine the relationship between family socio-economic status and maternal health care seeking behaviour in rural Bangladesh. In so doing, a total of 200 couples who have had a previous childbirth and lactating women were randomly selected from the Baliadangi Upazilla of Thakurgaon district, Bangladesh. The collected data were analyzed by Frequency Distribution, Cross-Tabulation and Partial Correlation techniques. The overall results suggested that socio-economic status (e.g. education, occupation and income) of Baliadangi women was a major factor in their health care seeking behaviour. The results of frequency distribution suggested that SES of Baliadangi couples was lower strata. Most of the couples were either illiterate or completed primary educational level. Like education, occupation and income level were also lower strata. Most of husbands were engaged in agricultural (49.5\%) and day labouring (40.0\%) activities and their wives were as housewife (89.5\%). The yearly average income of their family was 10000-19000 Tk. $(48.0 \%)$ which was not enough to maintain their family as well as maternal health services.

Medical check-up during pregnancy period, place of child birth, birth attendant and total number of child birth are the key factors for safe motherhood. The results suggested that maternal health care seeking behaviours of Baliadangi women were not satisfactory. Most of the women did not go to qualified doctor for medical check-up during their pregnancy period. Often they end up visiting village doctors or kobiraj. It is interesting to note that $70.2 \%$ women gave their child birth at home by untrained birth attendant to assist in the child delivery process and can pose serious risk to women's life.

The results of cross-tabulation suggested that maternal health care seeking behaviours ( e.g. medical check-up during pregnancy period, place of child birth, birth attendant and total number of child birth) varies in association with family socio-economic status (e.g. education, occupation and income) at Baliadangi Upazila of Thakurgaon District, Bangladesh. It is indicated that no education, agricultural work, day laboring, housewife and proportion of family income level $<10,000$ were highly associated to influence with no check-up during pregnancy, child birth at home, untrained birth attendant, and two or more child birth. In addition, the result of partial correlation there were positively or negatively inter-related between family SES and maternal health care seeking behaviour.

\section{CONCLUSION}

The present study finds that family socio-economic status highly affects on women's health care seeking behaviour in the study setting. Purpose of the study was to explore and examine family socio-economic status and maternal health care seeking behaviour in rural Bangladesh. Based on the result of frequency distribution, cross-tabulation and partial correlation test the findings suggest that family socio-economic status of Baliadangi couples was lower strata and because of that health care seeking behaviour of women also lower. The findings also suggest that family SES is an important factor for maternal health care seeking behaviour to ensure safe motherhood. The present study argues that due to dominance, inequality and deprivation in rural structure influence lower socio-economic groups and also influence to take more traditional and unofficial medical channels. This results are also supported by several researches in abroad and Bangladesh. The findings of the research provides important insights into our understanding the concept and may have a great direction for the policy maker to rethink and develop new policy in health sector to improve the health care seeking behaviour of rural women. Further research is essential to understand and generalization of the findings.

\section{REFERENCES}

[1] S. S. Ahmed; F. A. Islam, and Barkat Khuda, Neonatal morbidity and care seeking behaviour in rural Bangladesh. Journal of Tropical Pediatrics 1 April 47 (2), 2001, 98-105.

[2] S. Akter, Health care seeking behavior for safe motherhood: findings from rural Bangladesh. Bangladesh E-Journal of Sociology, 9(2), 2012, 57-70.

[3] A. C. Moran, P.J. Winch, N. Sultana, N. Kalim, K.M. Afzal, M. Koblinsky, et al. Patterns of maternal care seeking behaviours in rural Bangladesh. Tropical Medicine \& International Health, 12(7), 2007, 823-832.

[4] L.M. Walton, and B. Schbley, Cultural barriers to maternal health care in rural Bangladesh. Online Journal of Health Ethics, 9(1), 2013a.

[5] L.M. Walton, and B. Schbley, Maternal healthcare in Bangladesh and gender equity: a review article. Online Journal of Health Ethics, 9(1), 2013b.

[6] Z. Ali, Divergent maternal and child health outcomes in Bangladesh: a tale of two upazilas. The Bangladesh Development Studies, 33(3), 2010, 113-133. 
[7] S. Akter, and M.A Wohab, Millennium development goal of improving maternal health in Bangladesh: a review of concepts, BRAC University Journal, 1, 2008, 99-112.

[8] R. Amin, S.A. Chowdhury, G.M. Kamal, and J. Chowdhury, Community health services and health care utilization in rural Bangladesh, Social Science and Medicine, 29, 1989, 1343-1349.

[9] JC. Caldwell, Routes to low mortality in poor countries. Population and Development Review, 12, 1986, 171-220.

[10] M. Das Gupta, Death clustering, mother's education and the determinants of child mortality in rural Punjab, India. Population Studies, 44, 2004, 489-505.

[11] A. Levin, et al., The demand for child curative care in two rural thanas of Bangladesh: Effect of income and women's employment. International Journal Health Planning and Management, 16, 2001, 179-194.

[12] M. Haque, Individual's characteristics affecting maternal health services utilization: Married adolescents and their use of maternal health services in Bangladesh. Internet Journal of Health, 8(2),2009, p. 16.

[13] J. Grundy and P. Annear, Health-seeking behavior studies: a literature review of study design and methods with a focus on Cambodia. Nossal Institute for Global Health, the University of Melbourne, working paper series, 2010.

[14] M. Leininger, Transcultural care diversity and universality: A theory of nursing. Nursing and Health Care, 6 (4), 1985, 209-212.

[15] A. Sen, Development as Freedom. Oxford and New York: Oxford University Press, 2001.

[16] G. Tipping, and M. Segall, Health care seeking behaviour in developing countries: An annoted bibliography and literature review. Development Bibliography 2. Institute of Development Studies Sussex University, 1995.

[17] P. Sheeram, and Abraham, The health belief model. In M. Conner and P. Norman (ed): Predicting Health Behaviours: Research and Practice with Social Cognition Models. Buckingam. Open University Press, 1996, 23-61.

[18] R. Andersen, Revisiting the Behavioral Model and Access to Medical Care: Does it matter? Journal of Health and Social Behavior, 6(1), 1995, 1-10.

[19] Ministry of Health and Family Welfare, Health Bulletin, Baliadangi Upazila Health Complex, Bangladesh, 2012. 